DOI: https://doi.org/10.47405/mjssh.v6i8.960

\begin{tabular}{|c|c|}
\hline 4 & Malaysian Journal of Social Sciences and Humanities (MJSSH) \\
\hline $\begin{array}{l}\text { Malaysian Juoural of } \\
\text { Social ccciecces and }\end{array}$ & Volume 6, Issue 8, August 2021 \\
\hline (MJ-sSH) & e-ISSN : 2504-8562 \\
\hline & $\begin{array}{l}\text { Journal home page: } \\
\text { www.msocialsciences.com }\end{array}$ \\
\hline
\end{tabular}

\title{
Kesesuaian Langkah Memperkasakan Domain Bandar Berdaya Huni di Zon Black Spot Jenayah di Sabah
}

\author{
Norcikeyonn Samuni' ${ }^{\text {, Nor-Ina Kanyo² }}{ }^{\text {, Jabil Mapjabil }}{ }^{2}$ \\ 1Fakulti Sains Sosial Kemanusiaan, Universiti Malaysia Sabah (UMS) \\ 2Institut Kajian Orang Asal Borneo (BoRIIS), Universiti Malaysia Sabah (UMS) \\ Correspondence: Norcikeyonn Samuni (uncuyunn89@yahoo.com)
}

\begin{abstract}
Abstrak
Persoalan pangkal terhadap penyelesaian konflik ruangan perlu dilaksanakan segera antaranya untuk mewujudkan sebuah ruangan bandar yang berdaya huni untuk komuniti. Bagi mencapai matlamat keruangan tersebut, penekanan perlu diambil perhatian terhadap aspek keselamatan, keselesaan dan kesejahteraan ruangan fizikal. Justeru, dalam menyediakan ruangan fizikal seimbang, penelitian pemerkasaan berfokuskan kepada tiga domain bandar berdaya huni perlu dilakukan iaitu domain perumahan, domain ruang awam dan bangunan dan domain pengangkutan dan jalan raya. Makalah ini menjelaskan kesesuaian langkah memperkasakan domain bandar berdaya huni di zon black spot jenayah di Sabah merangkumi lima belas (15) zon black spot jenayah di sekitar Kota Kinabalu, Sandakan dan Tawau. Soal selidik diedarkan kepada 1,152 responden dan data dianalisis melalui SPSS menggunakan kaedah skor min. Penemuan mendapati langkah sesuai yang menjadi pilihan dominan responden bagi domain perumahan adalah melaksanakan aktiviti rondaan dan kawalan keselamatan tidak kira siang atau malam di kawasan perumahan (4.59). Manakala, domain ruang awam dan bangunan pula dengan memastikan pengurusan sisa pepejal adalah sistematik dengan nilai skor min (4.57). Sementara itu, domain pengangkutan dan jalan raya menekankan kekerapan menyelenggarakan jalan raya untuk kegunaan komuniti (4.62). Walau bagaimanapun, hasil analisis mengikut zon adalah berbeza mengikut ruangan dan lokasi. Oleh itu, adalah perlu pihak berwajib mengambil kira dan meneliti maklum balas komuniti dalam ruangan dalam memastikan usaha memperkasakan ruangan bandar berjalan baik.
\end{abstract}

Kata kunci: bandar berdaya huni, domain, zon black spot jenayah, komuniti, Sabah

\section{Appropriateness Measures to Empower the Domain of Livable Cities in The Black Spot Crime Zone in Sabah}

\begin{abstract}
The main question of conflict resolution should be implemented immediately among them to create a viable urban space for the community. To achieve the objective of the space, emphasis should be taken on the aspects of safety, comfort, and well-being of the physical space. Hence, in providing a balanced physical space, empowerment research focused on the three livable urban domains that are residential domains, public space domains and buildings and transport and road domains. This paper explains the appropriateness of measures to strengthen the livable urban domain in the crime black spot zone in Sabah, covering fifteen (15) crime black spot zones around Kota Kinabalu, Sandakan, and Tawau. Questionnaires were distributed to 1,152 respondents and data were analyzed through SPSS using the
\end{abstract}


mean score method. The findings found that the appropriate measure that is the dominant choice of respondents for the housing domain is to implement patrol activities and security control regardless of day or night in residential areas (4.59). Meanwhile, the domain of public space and buildings by ensuring solid waste management is systematic with a mean score value (4.57). Meanwhile, the transport and road domains emphasize the frequency of road maintenance for community use (4.62). However, the results of the analysis by zone differ by space and location. Therefore, it is necessary for the authorities to take into account and examine the feedback of the community in the space in ensuring that efforts to empower the urban space run smoothly.

Keywords: livable cities, domain, black spot crime zone, community, Sabah

\section{Pengenalan}

Imej bandar sering kali terjejas disebabkan oleh pelbagai masalah seperti kekurangan sumber air bersih, kesesakan lalu lintas, peningkatan kadar jenayah, kebanjiran pendatang asing dan sebagainya. Pelbagai tindakan telah dilakukan oleh kerajaan Malaysia bagi menangani masalah ini dalam memperbaiki kualiti hidup penduduk bandar dan seterusnya meningkatkan imej bandar (Zuriatunfadzliah, Noraziah \& Shaharudin, 2013). Menurut Norita, Nor-Ina dan Ahmad (2015) dalam kajiannya, pelaksanaan program bandar selamat di Sabah khususnya di Kota Kinabalu tidak mengikuti 23 langkah program yang digariskan dan dibahagikan kepada tiga strategi utama disebabkan oleh kekangan dana daripada kerajaan negeri. Justeru, disebabkan kelemahan ini mempengaruhi tahap keselamatan, kesejahteraan dan keselesaan komuniti bandar yang tinggal di kawasan yang dilabelkan sebagai kawasan hotspot. Konsep bandar selamat yang telah dilaksanakan di Sabah adalah bersifat mikro iaitu bahagian kecil dan penting sebagai titik tolak kepada peningkatan indeks daya huni bandar yang bersifat makro secara menyeluruh. Kehidupan manusia berkait rapat dengan keadaan alam sekitar di sekelilingnya yang mana turut menyediakan pelbagai jenis kemudahan kepada masyarakat untuk dimanfaatkan dalam pembangunan ekonomi. Pada masa sama, implikasi negatif terhadap penggunaan alam sekitar perlu segera ditangani dengan pendekatan secara holistik dan realistik oleh komuniti sebagai agen pembangunan ruangan (Jamilah et al., 2011). Hal ini kerana, komuniti yang mendiami sesebuah ruangan seharusnya memiliki sifat kepekaan dan kepemilikan kawasan yang tinggi dalam membantu mengatasi sebarang kerosakan mahupun kemusnahan dalam ruang lingkup persekitaran yang didiami.

Ciri-ciri pembangunan fizikalnya perlu ditambahbaikkan bagi membangunkan bandar yang lestari sekali gus mewujudkan bandar berdaya huni meliputi ruang yang bersih, selamat, penyediaan kemudahan komuniti, taman dan kawasan lapang, kawasan hiburan, teknologi pengangkutan dan komunikasi, kesihatan mental dan fizikal, kesihatan komuniti serta struktur kejiranan (Mohd Yusof \& Lukman, 2002). Oleh itu, ianya bergantung kepada ketegasan yang harus dilakukan oleh manusia sendiri dalam memelihara dan mengekalkan pembangunan supaya hubungan manusia dengan alam dan manusia dengan pembangunan dalam keadaan yang sejahtera. Konsep livable itu sendiri membawa maksud yang sangat besar dan ianya berfokus kepada peningkatan kualiti hidup penghuni yang tinggal di dalamnya dalam aspek peningkatan akses kemudahan sama ada pengangkutan, perumahan, ruang awam dan lain-lain. Justeru, makalah ini akan menjelaskan langkah yang dicadangkan untuk memperkasakan domain bandar berdaya huni di lima belas (15) zon black spot jenayah yang terlibat berdasarkan maklum balas komuniti. Terdapat tiga domain bandar berdaya huni diketengahkan iaitu domain perumahan, domain ruang awam dan bangunan, dan domain pengangkutan dan jalan raya.

\section{Metod Kajian}

Pemilihan Sabah khususnya di tiga kawasan hotpsot jenayah iaitu Kota Kinabalu, Sandakan dan Tawau dalam makalah ini disebabkan fokus pengkajian berkaitan komuniti bandar. Sebagai sebuah pusat perkembangan ekonomi negara, bandar menjadi tumpuan penduduk untuk berhijrah bagi 
DOI: https://doi.org/10.47405/mjssh.v6i8.960

mendapatkan pekerjaan. Zon Black spot membawa makna titik hitam atau kawasan hotspot berdasarkan kadar jenayah tinggi dicatatkan. Black spot juga adalah terma yang digunakan sebagai kawasan yang didefinisikan sebagai kawasan yang mampu memberi semua ancaman kepada manusia sama ada dari aspek persekitaran fizikal, sosial dan mental. Secara umumnya, konsep bandar selamat yang dilaksanakan di zon black spot membawa makna bandar yang bebas dari semua ancaman fizikal, sosial dan mental. Jadual 1 merupakan senarai zon black spot jenayah yang terlibat dalam kajian ini.

Jadual 1: Label 15 Zon Black Spot Jenayah di Sabah

\begin{tabular}{llllll}
\hline \multicolumn{2}{l}{ Kota Kinabalu } & Sandakan & & Tawau & \\
\hline Zon 1 & Saadong Jaya & Zon 6 & Flat Indah Jaya & Zon 11 & Fajar \\
Zon 2 & Segama & Zon 7 & Pasar Kim Fung & Zon 12 & Batu 2 \\
Zon 3 & Sembulan & Zon 8 & Flat Karamunting & Zon 13 & Sabindo \\
Zon 4 & Sinsuran & Zon 9 & Pasar Umum & Zon 14 & Taman Semarak \\
Zon 5 & Tanjung Aru & Zon 10 & Stesen Bas Labuk & Zon 15 & Titingan \\
\hline
\end{tabular}

Seramai 1,152 orang responden dari lima belas (15) zon black spot jenayah di tiga bandar utama Sabah iaitu Kota Kinabalu, Sandakan dan Tawau terlibat dalam kajian ini. Kutipan data menggunakan sumber data primer yang diperoleh daripada soal selidik kepada responden. Kaedah analisis digunakan menggunakan analisis skor min melalui perisian SPSS. Data soal selidik menggunakan analisis skor min menggunakan interpretasi skor min hasil pengubahsuaian daripada Zulkifli (2012) dimana tahap kecenderungan item soal selidik ditentukan seperti nilai berikut iaitu T: Tinggi (1.00 hingga 2.49), S: Sederhana (2.50 hingga 3.79) dan R: Rendah (3.80 hingga 5.00).

\section{Hasil Kajian}

\section{Profil Responden}

Profil responden yang telah terlibat dalam kajian ini adalah seperti yang terdapat pada jadual 2.

Jadual 2: Profil Responden

\begin{tabular}{ll}
\hline Profil & Jumlah Responden (\%) \\
\hline Jantina & Lelaki $(45.4 \%)$, Perempuan (54.6\%) \\
Umur & $18-29$ tahun $(38.8 \%), 30-40$ tahun $(37.7 \%), 41-59$ tahun (19.1\%), > 60 tahun \\
& $(4.4 \%)$ \\
Etnik & Melayu (15.1\%), Cina (7.4\%), India (3.3\%), Bumiputera (67.9\%), Lain-lain (6.3 \\
& $\%)$ \\
Pendidikan & Tiada pendidikan (8.0\%), Rendah (11.9\%), Menengah (42.8\%), Tertiari (37.3\%) \\
Pekerjaan & Swasta (44.3\%), Kerajaan (12.2\%), Sendiri (34.0\%), Tidak bekerja (9.5 \%) \\
Status & Bujang (50.3\%), Berkahwin (49.7\%) \\
\hline
\end{tabular}

\section{Kesesuaian Langkah Memperkasakan Domain Bandar Berdaya Huni}

Dalam bahagian ini, kesesuaian langkah memperkasakan domain bandar berdaya huni yang diperincikan melalui analisis skor min seperti dalam Jadual 3. Melalui domain perumahan, terdapat tiga (3) langkah, domain ruang awam dan bangunan mempunyai empat (4) langkah dan domain pengangkutan dan jalan raya pula sebanyak tiga (3) langkah disenaraikan. 
Jadual 3: Cadangan Langkah Memperkasakan Domain Bandar Berdaya Huni di Zon Black Spot Jenayah di Sabah

\begin{tabular}{|c|c|c|c|c|c|c|c|c|c|c|c|}
\hline \multirow{3}{*}{ Lokasi } & \multirow{3}{*}{$\begin{array}{c}\text { Zon } \\
(\text { BSJ })\end{array}$} & \multicolumn{3}{|c|}{ Domain Perumahan } & \multicolumn{4}{|c|}{ Domain Ruang Awam dan Bangunan } & \multicolumn{3}{|c|}{$\begin{array}{c}\text { Domain Pengangkutan dan Jalan } \\
\text { Raya }\end{array}$} \\
\hline & & Langkah & Langkah & Langkah & Langkah & Langkah & Langkah & Langkah & Langkah & Langkah & Langkah \\
\hline & & 1 & 2 & 3 & 1 & 2 & 3 & 4 & 1 & 2 & 3 \\
\hline \multirow{5}{*}{$\begin{array}{c}\text { Kota } \\
\text { Kinabalu }\end{array}$} & Zon 1 & 4.67 & 3.84 & 4.41 & 3.88 & 3.57 & 4.57 & 4.71 & 3.87 & 4.66 & 3.85 \\
\hline & Zon 2 & 4.61 & 3.83 & 4.46 & 3.77 & 3.79 & 4.76 & 4.63 & 3.77 & 4.75 & 3.66 \\
\hline & Zon 3 & 4.63 & 3.81 & 4.44 & 3.89 & 3.51 & 4.77 & 4.62 & 3.77 & 4.72 & 3.66 \\
\hline & Zon 4 & 4.63 & 3.75 & 4.46 & 3.82 & 3.76 & 4.86 & 4.72 & 3.63 & 4.71 & 3.67 \\
\hline & Zon 5 & 4.71 & 3.72 & 4.45 & 4.09 & 3.70 & 4.09 & 4.61 & 3.88 & 4.75 & 3.85 \\
\hline \multirow{5}{*}{ Sandakan } & Zon 6 & 4.40 & 4.83 & 4.15 & 3.93 & 3.71 & 3.97 & 4.72 & 3.96 & 4.57 & 3.88 \\
\hline & Zon 7 & 4.72 & 3.85 & 4.42 & 3.76 & 3.55 & 4.56 & 4.36 & 3.72 & 4.39 & 4.47 \\
\hline & Zon 8 & 4.51 & 4.20 & 4.44 & 3.89 & 3.54 & 4.79 & 4.46 & 3.77 & 4.66 & 3.67 \\
\hline & Zon 9 & 4.68 & 4.10 & 4.40 & 3.79 & 3.77 & 4.53 & 4.84 & 3.77 & 4.62 & 3.66 \\
\hline & Zon 10 & 4.75 & 3.75 & 4.19 & 3.77 & 3.80 & 4.70 & 4.35 & 3.68 & 4.66 & 3.76 \\
\hline \multirow{5}{*}{ Tawau } & Zon 11 & 3.97 & 3.59 & 4.76 & 4.09 & 3.70 & 4.42 & 4.37 & 3.88 & 4.59 & 3.85 \\
\hline & Zon 12 & 4.81 & 3.84 & 4.44 & 3.88 & 3.57 & 4.59 & 4.45 & 4.01 & 4.51 & 3.85 \\
\hline & Zon 13 & 4.59 & 3.81 & 4.47 & 3.89 & 3.52 & 4.53 & 4.44 & 4.09 & 4.47 & 4.14 \\
\hline & Zon 14 & 4.46 & 4.57 & 4.46 & 3.75 & 3.77 & 4.61 & 4.62 & 3.77 & 4.58 & 3.66 \\
\hline & Zon 15 & 4.77 & 3.75 & 4.41 & 3.71 & 3.76 & 4.49 & 4.71 & 3.63 & 4.67 & 4.12 \\
\hline \multirow{2}{*}{ Output } & Median & 4.59 & 3.95 & 4.42 & 3.86 & 3.67 & 4.55 & 4.57 & 3.81 & 4.62 & 3.85 \\
\hline & Skala & $\mathbf{T}$ & $\mathrm{T}$ & $\mathrm{T}$ & $\mathrm{T}$ & $\mathrm{S}$ & $\mathrm{T}$ & $\mathbf{T}$ & $\mathrm{T}$ & $\mathbf{T}$ & $\mathrm{T}$ \\
\hline
\end{tabular}




\section{Perbincangan Kajian}

\section{Kesesuaian Langkah Memperkasakan Domain Perumahan}

Hasil analisis mendapati bahawa, secara majoritinya responden bersetuju bahawa langkah melaksanakan aktiviti rondaan dan kawalan keselamatan tidak kira siang atau malam di kawasan perumahan adalah paling sesuai dan berkesan dilaksanakan untuk memperkasakan lagi domain perumahan dengan nilai skor min (4.59) dan mencapai skala tahap tinggi, diikuti dengan langkah menyediakan papan tanda keselamatan dan saluran komunikasi bagi kes kecemasan (4.42) dan menyediakan konsep kawasan komuniti berpagar (3.95).

\section{Melaksanakan Aktiviti Rondaan dan Kawalan Keselamatan Pada Waktu Siang dan Malam}

Disebabkan rasa semangat cintakan keamanan walaupun tidak mendapat gaji mahupun elaun tetap, anggota Skim Rondaan Sukarela (SRS) tetap komited membantu Polis Diraja Malaysia (PDRM) menjaga keselamatan dan keamanan setempat (Utusan Borneo, 11 Februari 2019). Setiap anggota SRS dilengkapi dengan baju vest bercahaya, lampu suluh dan cota semasa membuat rondaan cegah jenayah. Di samping itu, mereka mempunyai kuasa menahan seseorang yang mencurigakan di kawasan taman perumahan mereka sebelum dilaporkan kepada polis untuk tindakan lanjut. Kewujudan SRS juga dilihat telah berjaya mencegah banyak kes jenayah seperti ragut, pecah rumah dan kenderaan di kawasan perumahan. Pelaksanaan program bandar selamat di Sabah di bawah Inisiatif Pemutihan Kawasan diperkenalkan dengan fokus utama untuk mengurangkan kadar jenayah dan meningkatkan persepsi rasa selamat dalam kalangan orang awam.

Tiga (3) skop utama pelaksanaan program pemutihan kawasan blackspot iaitu meliputi projek fizikal, sosial dan operasi keselamatan. Pelaksanaan projek fizikal meliputi langkah-langkah Bandar Selamat iaitu pencahayaan, laluan pejalan kaki khusus, rel penghadang, tempat letak motosikal berkunci, papan tanda keselamatan, cermin keselamatan dan redaan trafik. Melalui program sosial pula, pelbagai program berbentuk sosial dan kemasyarakatan turut dilaksanakan oleh agensi-agensi berkaitan seperti gotong royong, pemulihan serta rawatan dadah, sesi dialog bersama penduduk dan sebagainya bagi memperkasakan lagi penglibatan komuniti dalam menjadikan sesebuah ruangan itu selamat, selesa dan sejahtera. Operasi Keselamatan pula kebiasaannya meliputi aktiviti penguatkuasaan keselamatan seperti rondaan bersepadu oleh PDRM, PBT, Rela, KRT, operasi PATI, Community Policing dan sebagainya, (JPBD, 2019).

\section{Menyediakan Papan Tanda Keselamatan dan Saluran Komunikasi Bagi Kes Kecemasan}

Cadangan langkah yang mendapat maklum balas kedua tertinggi adalah menyediakan papan tanda keselamatan dan saluran komunikasi bagi kes kecemasan dengan nilai skor min (4.4280). Papan Tanda Keselamatan adalah salah satu dari komunikasi kepada dan pelawat daripada luar kawasan mengenai risiko, bahan berbahaya di satu-satu satu kawasan. Papan tanda yang efektif perlu mudah dibaca dan dikenal pasti. Secara umumnya papan tanda yang sering digunakan adalah "AMARAN", "BAHAYA' yang sering digunakan di kawasan yang mempunyai risiko yang tinggi seperti tapak bina, bahan berbahaya di dalam makmal. Bagi kawasan yang mempunyai risiko yang rendah terdapat keperluan untuk meletakkan papan tanda keselamatan seperti yang berkaitan dengan bahaya kebakaran, arah keluar dan apa yang diperlukan atau tidak boleh dilakukan di kawasan berkenaan. Terdapat beberapa Jenis jenis papan tanda iaitu papan tanda mandatori, keadaan selamat, papan tanda melawan kebakaran, papan tanda amaran dan papan tanda larangan, Occupational Safety \& Health Management Office, Universiti Malaysia Pahang (OSHMO), (2019). 


\section{Menyediakan Konsep Kawasan Komuniti Berpagar}

Langkah ketiga pula adalah dengan menyediakan konsep kawasan komuniti berpagar dengan nilai skor min (3.95). Kebelakangan ini, perumahan berkonsepkan berpagar dan berpengawal menjadi semakin popular dan mula diaplikasikan kepada pemajuan perumahan hartanah. Blakely dan Synder (1997) mengklasifikasikan pembangunan komuniti berpagar kepada empat kriteria, iaitu fungsi pemagaran dan tembok, ciri-ciri keselamatan dan kawalan, kemudahan dan fasiliti serta jenis perumahan yang akan dibangunkan. Berdasarkan Laporan JPBD dan KPKT (2010), pembangunan komuniti berpagar adalah berdasarkan tiga (3) kriteria iaitu (1) Komuniti berpagar boleh dibangunkan di kawasan bandar besar terutamanya di kawasan yang mempunyai kadar jenayah yang tinggi, tertakluk kepada tafsiran pihak berkuasa tempatan, (2) Komuniti berpagar seharusnya boleh dibenarkan untuk dibangunkan di kawasan yang mempunyai jaringan jalan perhubungan yang baik dan di persekitaran yang telah maju, (3) Tertakluk kepada tafsiran Pihak Berkuasa Tempatan (PBT), Komuniti berpagar tidak digalakkan dibangunkan di kawasan berhampiran dengan kampung kerana dikhuatiri ia memberi impak negatif (Zurinah \& Jalaludin, 2018).

\section{Kesesuaian Langkah Memperkasakan Domain Ruang Awam dan Bangunan}

Terdapat empat cadangan langkah untuk memperkasakan domain ruang awam dan bangunan dalam usaha menjadikan bandar berdaya huni di setiap zon black spot jenayah di Sabah diperincikan seperti dalam Jadual 3 iaitu (1) Memelihara taman-taman awam, (2) Menyediakan laluan khas bagi pejalan kaki dan penunggang basikal, (3) Menyelenggarakan dan memelihara keadaan bangunan dan kemudahan awam dan (4) Memastikan pengurusan sisa pepejal adalah sistematik. Hasil analisis skor min keseluruhan bagi cadangan langkah untuk memperkasakan domain ruang awam dan bangunan dalam usaha menjadikan bandar berdaya huni di setiap zon black spot jenayah di Sabah mendapati langkah memastikan pengurusan sisa pepejal adalah sistematik dengan nilai skor min (4.57) dan mencapai skala tinggi. Disusuli dengan langkah menyelenggarakan dan memelihara keadaan bangunan dan kemudahan awam (4.55), Memelihara taman-taman awam (3.86) dan Menyediakan laluan khas bagi pejalan kaki dan penunggang basikal (3.67) yang cuma mencapai skala tahap 'sederhana'. Persekitaran adalah ruang yang penting kepada kehidupan komuniti kerana, secara normatifnya, persekitaran yang bersih boleh menjamin keselesaan dan kesejahteraan hidup penghuni. Keadaan persekitaran yang bersih adalah hasil daripada usaha menjaga dan memelihara kebersihan ruang peribadi, sepunya, dan awam oleh pelbagai peringkat komuniti dan pihak berkuasa (Mohd. Yusof, et. al, 2010). Usaha menjaga dan memelihara ruang persekitaran ini berkait dengan soal kesedaran dan sikap komuniti untuk memastikan persekitaran itu sentiasa bersih dan sihat untuk didiami.

\section{Memastikan Pengurusan Sisa Pepejal Adalah Sistematik}

Pengurusan sisa pepejal dan pelupusan terbuka Sifar Menjelang 2020 secara bersepadu bukan sekadar matlamat tetapi merupakan satu usaha ke arah menguruskan sisa pepejal hasil aktiviti manusia serta menjaga alam sekitar yang tercemar. Penjagaan alam sekitar adalah sangat penting kerana ia merupakan aset penting kepada kesejahteraan hidup manusia (Augustine, 2017). Pelbagai langkah sesuai boleh dilaksanakan dalam memastikan pengurusan sisa pepejal adalah sistematik iaitu PBT perlu melakukan pemantauan ke atas badan yang dipertanggungjawabkan khasnya Jabatan Alam Sekitar (JAS), memberi kuasa kepada PBT semula untuk menguruskan sisa pepejal, melaksanakan standard kualiti pengurusan sisa pepejal, menyediakan lebih banyak tong kitar semula, mengurangkan pengeluaran plastik, penggunaan teknologi moden dalam pelupusan sisa pepejal, memperketat kajian kesan pembangunan ke atas alam sekitar dan memperbanyakkan program pendidikan kitar semula, memperkasakan peranan pertubuhan bukan kerajaan (NGO), individu serta masyarakat setempat, mengitar semula bahan buangan dalam syarikat, menganjurkan hari kitar semula, program kitar semula dari rumah, amalan hijau membeli-belah, merancang destinasi semasa pergi membeli-belah dan barangan yang hendak dibeli, membawa beg sendiri semasa membeli-belah dan membuang sampah pada tempat yang betul. Dengan mengambil kira kepada pelbagai langkah ini sebagai amalan pengurusan sisa pepejal domestik secara harian, ianya akan dapat menyumbang kepada keefektifan langkah menguruskan sisa. 


\section{Menyelenggara dan Memelihara Keadaan Bangunan serta Kemudahan Awam}

Merujuk kepada Haas dan Hudson (1978), definisi penyelenggaraan berbeza mengikut amalan agensi. Secara dasarnya, penyelenggaraan meliputi satu set aktiviti yang pada akhirnya membolehkan sesuatu benda atau peralatan dapat digunakan dengan baik. Matlamat utama penyelenggaraan bangunan adalah untuk mengurangkan seberapa mungkin kegagalan dan kecacatan terhadap elemen dan peralatan bangunan secara efektif dan sistematik. Secara tidak langsung, segala aspek keselamatan dan keselesaan akan lebih terjamin bukan sahaja kepada pengguna malah kepada pemilik. Sebarang kegagalan dan ketidaksempurnaan pengurusan bangunan boleh memberi kesan tidak baik kepada setiap komuniti yang telah berada di dalam persekitaran bangunan. Penyelenggaraan terancang adalah kerja penyelenggaraan yang diorganisasikan, dilaksanakan, dikawal dan dibentuk berdasarkan perancangan yang telah dibuat terlebih dahulu dengan mengambil kira kemungkinan yang akan berdasarkan kepada rekod lalu (A. Raouf \& Ben-Daya, 1995).

Penyelenggaraan terancang penting kerana ia dapat mengurangkan risiko kerosakan yang akan berlaku ke atas sesuatu elemen pada bangunan dan ia dapat mengurangkan kos penyelenggaraan, dan menghalang kegagalan yang berulang (Akasah, 2008). Faktor yang penting dalam penyelenggaraan bangunan yang perlu diberikan perhatian adalah untuk memastikan semua penghuni bangunan selesa, selamat dan sihat semasa menghuni sesebuah bangunan. Pelbagai faktor turut terlibat bagi mencapai perkhidmatan berkualiti, selamat dan sihat dalam bangunan seperti objektif, dasar dan strategi, perancangan, kewangan, prosedur, peraturan dan piawaian serta sumber manusia. Pelbagai peraturan, akta dan piawaian telah diwujudkan di Malaysia bagi memudahkan pengurusan fasiliti atau kemudahan memberikan perkhidmatan terbaik terutama aspek penyelenggaraan bangunan. Selain itu kewujudan tiga jenis sistem pengurusan iaitu Sistem Pengurusan Kualiti (MS ISO 9001:2000), Sistem Pengurusan Persekitaran (MS ISO 14001:2004) dan Sistem Pengurusan Keselamatan dan Kesihatan Pekerjaan (OHSAS 18001:2007) mampu menjadi panduan bagi mempertingkatkan prestasi perkhidmatan dalam pengurusan fasiliti.

\section{Memelihara Taman-Taman Awam}

Taman rekreasi atau juga dikenali sebagai taman awam merupakan kawasan yang dibangunkan untuk memenuhi keperluan kawasan lapang yang memenuhi kepentingan serta mampu berfungsi di samping dapat memberi manfaat kepada pengguna (Rosniza \& Nur Efazainiza, 2019). Kerajaan telah membangunkan taman dan ujana awam untuk menampung keperluan penduduk terutama di kawasan Bandar dan pinggir bandar. Matlamat utamanya adalah untuk menjayakan pencapaian kualiti kehidupan yang menyeluruh (Total Quality Living Environment) dengan tumpuan kepada mutu persekitaran kehidupan yang indah, bersih dan selamat. Penyediaan taman dan ujana awam dapat memberikan ruang yang selesa daripada impak rekreasi dan keindahan alam di sekitar kawasan penduduk setempat, selain memberi peluang penduduk berinteraksi antara satu sama lain yang akan membantu integrasi sosial dan kesejahteraan hidup rakyat. Kewujudan taman-taman ini di kawasan bandar dapat membantu usaha untuk mengurangkan kesan pulau haba. Oleh sebab, pembangunan taman dan ujana awam banyak membawa kesan positif kepada masyarakat.

Sewajarnya, anggota masyarakat memainkan peranan dan penyelenggaraan dan pengurusan aktiviti di kawasan berkenaan. Sehubungan dengan itu, Projek Naik Taraf Taman Awam adalah bertujuan menambah dan menaik taraf fungsi kualiti kemudahan rekreasi di taman kejiranan dan taman awam sedia ada. Ini adalah untuk memastikan kemudahan rekreasi di kawasan PBT berada dalam keadaan baik, selamat dan berfungsi. Skop Projek Naik Taraf Taman Awam merangkumi naik taraf reke bentuk taman, naik taraf kemudahan taman, naik taraf alat permainan dan senaman serta baik pulih komponen landskap. Kriteria pemilihan tapak adalah (1) taman-taman kejiranan dan taman awam sedia ada yang bersaiz sekurang-kurang nya 3 ekar, (2) hak milik atau kawal selia oleh pbt dan diwartakan atau rizab sebagai kawasan lapang, (3) kawasan yang menjadi tumpuan dan berpotensi untuk dibangunkan, (4) bebas dari bencana serta mempunyai kemudahsampaian yang baik dan (5) keutamaan kepada PBT yang mempunyai unit atau bahagian landskap (KPKT, 2019). 


\section{Menyediakan Laluan Pedestrian dan Penunggang Basikal}

Peraturan penggunaan lintasan pejalan kaki telah dikeluarkan bagi memastikan keselamatan pengguna jalan raya. Umumnya, laluan pejalan kaki terbahagi kepada dua jenis iaitu lorong pejalan kaki (walkways) iaitu lorong khas yang dibina daripada turapan, konkrit atau batu-bata untuk pejalan kaki dan ianya menghubungkan satu tempat dengan tempat yang lain. Manakala, Siar kaki (sidewalks) pula biasanya dibina juga daripada turapan, konkrit atau batu-bata serta mempunyai aras yang tinggi sedikit daripada permukaan jalan tetapi terletak di sebelah jalan dan ada kalanya dipisahkan dengan tanaman yang selari dengan jalan. Lokasi-lokasi yang boleh disediakan fasiliti laluan pejalan kaki adalah seperti aktiviti pejabat, perniagaan dan kawasan kediaman, kawasan-kawasan dalam bandar, rumah ibadat, lintasan searas atau jejantas, sekolah, perhentian bas, kawasan rekreasi dan kesukanan serta tempat kebudayaan dan pelancongan.

Seterusnya adalah berkaitan dengan laluan penunggang basikal perlu disediakan di ruang awam. Pengangkutan kenderaan tidak bermotor merupakan pengangkutan alternatif yang bersifat ekonomi, mesra alam serta mewujudkan persekitaran yang bersih, sihat dan berkualiti tinggi (Muhamad et al., 2013). Salah satu mod pengangkutan tidak bermotor ialah berbasikal yang diketengahkan sebagai salah satu alternatif terhadap mod pengangkutan yang mampan. Penggunaan mod pengangkutan aktif (basikal) mampu mengurangkan pelepasan gas berbahaya dari kenderaan dan mengawal pencemaran udara serta alam sekitar (Balsas, 2003). Terdapat beberapa faktor yang turut mempengaruhi penggunaan basikal dan ianya perlu diambil perhatian seperti penyediaan kemudahan untuk berbasikal seperti laluan khas, kehadiran pengawal keselamatan serta penyediaan lampu di setiap laluan bagi mengelakkan kejadian jenayah ke atas penunggang basikal (Sahar, Muhammad \& Reza, 2015).

Penyediaan laluan khas bagi pedestrian dan penunggang basikal adalah sangat penting bagi memastikan keselamatan dan keselesaan pengguna di ruang awam lebih terjamin. Tambahan lagi budaya berbasikal misalnya telah menjadi trend dalam kalangan masyarakat sebagai salah satu hobi gaya hidup sihat yang dilaksanakan secara berkumpulan. Trend ini telah menimbulkan beberapa isu khususnya berkaitan keselamatan kerana ada sesetengah penunggang menggunakan beberapa laluan lebuh raya sehingga mengundang bahaya kepada pengguna jalan raya yang lain terutamanya bagi pemandu baru yang masih belum memahami garis panduan keselamatan, (Bernama, 11 September 2020). Selain itu, terdapat juga khidmat Food Panda secara mod berbasikal dan jalan kaki disediakan terutamanya di kawasan-kawasan bandar dan taman perumahan.

\section{Kesesuaian Langkah Memperkasakan Domain Pengangkutan dan Jalan Raya}

Terdapat tiga cadangan langkah untuk memperkasakan domain pengangkutan dan jalan raya dalam usaha menjadikan bandar berdaya huni seperti dalam Jadual 3 iaitu (1) Memastikan pengangkutan awam selamat digunakan, (2) Kerap menyelenggarakan jalan raya untuk kegunaan komuniti dan (3) Pemerkasaan undang-undang kepada pengguna jalan raya. Hasil analisis skor min secara keseluruhan bagi lima belas (15) zon dijelaskan mendapati bahawa langkah kerap menyelenggarakan jalan raya untuk kegunaan komuniti adalah yang paling sesuai dengan nilai skor min (4.62), diikuti dengan Pemerkasaan undang-undang kepada pengguna jalan raya (3.85) dan Memastikan pengangkutan awam selamat digunakan yang mana semuanya mencapai skala tahap 'tinggi'. Berdasarkan statistik yang dikeluarkan oleh PDRM, kemalangan jalan raya dan kecederaan yang berlaku di Malaysia mencatatkan jumlah peningkatan dari tahun ke tahun. Bermula dari tahun 2011 kes dicatatkan sebanyak 449,040 dan meningkat naik sebanyak 118,476 kes kepada 567,516 kes pada tahun 2019. Statistik ini menunjukkan suatu keadaan yang membimbangkan khususnya dalam aspek keselamatan pengguna jalan raya. Kemalangan jalan raya merupakan antara penyebab penting kepada kematian dan kecederaan yang mengancam kesejahteraan hidup masyarakat. Kecederaan trafik merupakan penyebab kematian keenam tertinggi di Malaysia bermula tahun 2006 lalu (Nizam et. al, 2011). Oleh itu, bagi memastikan dan mengurangkan jumlah kes yang kian meruncing ini, perlu adanya langkah yang efektif khususnya dalam aspek pemerkasaan domain pengangkutan dan jalan raya di Malaysia. Langkah utama yang menjadi pilihan responden iaitu kekerapan penyelenggaraan jalan raya untuk kegunaan masyarakat. 


\section{Kerap Menyelenggara Jalan Raya Untuk Semua Pengguna}

Menurut Laporan Ketua Audit Negara Tahun 2018, Siri 2, berdasarkan Road Condition Index menunjukkan 55.3 peratus jalan berturap di Sabah berada di bawah skala 3 (sederhana) dan skala 4 (teruk) yang memerlukan penyelenggaraan berkala, manakala 4.5 peratus berada di bawah skala 5 (jalan tidak boleh disenggarakan) yang memerlukan kerja pembinaan semula. Pengauditan yang dijalankan antara bulan Oktober 2018 hingga Januari 2019 turut mendapati wujud kelemahan dalam aspek pencapaian kewangan, kualiti kerja penyelenggaraan, pentadbiran kontrak dan pemantauan yang perlu ditambah baik untuk meningkatkan kecekapan pengurusan penyelenggaraan jalan di Sabah. Pengurusan penyelenggaraan jalan berturap Sabah adalah di bawah Jabatan Kerja Raya (JKR) negeri (Bernama, 21 April 2020). Penyelenggaraan yang mencukupi dapat mengelakkan kerosakan jalan menjadi lebih teruk dan memerlukan kos penyelenggaraan dan pembaikan lebih tinggi pada masa hadapan. JKR juga perlu meningkatkan pemeriksaan dan pemantauan untuk memastikan kerja penyelenggaraan rutin yang dilaksanakan oleh konsesi dan kontraktor penyelenggaraan mematuhi syarat kontrak dan berkualiti.

Kontraktor penyelenggaraan yang diamanahkan memantau dan menjaga keadaan jalan raya di Sabah perlu memastikan kemudahan ini dalam keadaan baik dan selamat digunakan sepanjang masa. Terdapat kekeliruan yang dihadapi oleh masyarakat dalam menyalurkan aduan berkenaan dengan kerosakan jalan raya. Kebanyakan aduan diajukan kepada Kementerian Kerja Raya (KKR), sedangkan jalan raya adalah di bawah pengurusan Kementerian Pembangunan Luar bandar, Majlis Daerah atau jalan estet oleh pihak pengurusan estet yang terlibat. Bank data jalan raya ini perlu, bagi memastikan jalan raya dikendalikan oleh pihak mana, selain memudahkan pihak kerajaan menyalurkan peruntukan sama ada untuk membaiki kerosakan atau menaik taraf jalan raya terbabit. Operasi penyenggaraan jalan raya perlu dilaksanakan secara terancang berdasarkan kepada restorative (penjagaan) dan preventif (pengelakkan). Dasar penyenggaraan ini dikategorikan kepada Penyenggaraan kecemasan (immediate), Penyenggaraan semasa (routine), Penyenggaraan berkala (periodic) dan Pemulihan (rehabilitation) (Kementerian Kerja Raya, 2019).

\section{Pemerkasaan Undang-Undang Kepada Pengguna Jalan Raya}

Salah laku jalan raya bermaksud tindak tanduk pengguna jalan raya yang salah, dan mungkin membawa kepada kemalangan jalan raya. Dalam konteks etika salah laku jalan raya biasanya berkait dengan sikap pengguna jalan raya dan bukan kemahiran pengguna jalan raya itu sendiri. Salah laku jalan raya merupakan sesuatu yang mengancam keselamatan jalan raya dan juga pengguna jalan raya yang lain. Bagi menyelesaikan masalah salah laku jalan raya, pihak penguat kuasa seharusnya tidak mengambil pendekatan penyelesaian mudah seperti hanya menjalankan kempen. Kemalangan jalan raya boleh dikurangkan dengan pendekatan kaedah 3E iaitu (Engineering, Education, dan Enforcement). Langkah yang boleh dilakukan dalam pendekatan kejuruteraan ialah dengan menyediakan persekitaran yang lebih selesa kepada pengguna seperti melebarkan dan meluruskan jalan raya sempit dan berselekoh, menyediakan papan tanda yang jelas, menyediakan lorong pejalan kaki dan laluan motosikal, persimpangan yang teratur dan lampu jalan yang terang. Pendekatan pendidikan adalah bertujuan untuk memberikan kesedaran kepada pengguna jalan raya supaya berhemah dan berdisiplin semasa di jalan raya seperti mengadakan kempen keselamatan jalan raya. Sementara pendekatan penguatkuasaan pula bertujuan untuk mengubah kelakuan dan sikap pengguna jalan raya. Penguatkuasaan undang-undang adalah merupakan kaedah yang lebih berkesan untuk mengubah kelakuan dan tabiat manusia jika dibandingkan dengan kaedah pendidikan. Hasilnya boleh dilihat dengan penurunan kemalangan dan kematian setiap kali apabila pihak polis melancarkan Ops Statik di sepanjang tempoh tertentu semasa adanya perayaan (Radin, 1998). Punca utama kemalangan majoritinya disebabkan oleh pengguna terbabas sendiri iaitu melibatkan satu kenderaan, diikuti dengan cubaan memotong atau tukar lane dan cuai ketika keluar masuk di persimpangan jalan.

Akta Pengangkutan Jalan 1987 (Akta 333) digunakan untuk aktiviti penguatkuasaan undang-undang melibatkan salah laku pengguna jalan. Jabatan Pengangkutan Jalan (JPJ) juga sedang mengkaji untuk menyelaraskan semula penguatkuasaan undang-undang terhadap aktiviti berbasikal di jalan raya. Pada tahun 2007, Kabinet telah memutuskan supaya Kod Amalan Keselamatan, Kesihatan dan Alam Sekitar (SHE) dilaksanakan dalam sektor pengangkutan khususnya pengangkutan awam. Setelah 
beberapa tahun kod SHE dilaksanakan, JKKP telah mengambil inisiatif untuk menyemak semula kandungan dan skop pelaksanaan kod SHE ini agar ia dapat dilaksanakan dengan lebih berkesan. Dengan bantuan dan kerjasama daripada pihak agensi kerajaan yang berkaitan, pertubuhan bukan kerajaan dan pihak industri, JKKP telah berjaya menyediakan satu kod baru yang dinamakan sebagai Tataamalan Industri Keselamatan Dan Kesihatan Pekerjaan Bagi Aktiviti Pengangkutan Jalan 2010. Tataamalan Industri ini telah diwartakan di bawah subseksyen 37(4) Akta Keselamatan dan Kesihatan Pekerjaan 1994 [Akta 514]. Tataamalan Industri ini bertujuan untuk memberikan maklumat dan panduan yang praktikal kepada pihak majikan dalam memenuhi tanggungjawab am mereka untuk memastikan keselamatan dan kesihatan pekerja mereka dan juga orang awam. Selain itu, maklumat berkenaan dengan pengurusan keselamatan dan kesihatan pekerjaan di tempat kerja terutamanya aspek pengurusan pemandu, pengurusan kenderaan, dan juga pengurusan perjalanan dan risiko. Kesemua aspek pengurusan ini sangat penting bagi memastikan majikan, pekerja, pemandu, dan kenderaan sentiasa berada dalam keadaan yang selamat. Seterusnya, dapat mengelakkan kemalangan sama ada di tempat kerja dan di jalan raya daripada berlaku (Jabatan Keselamatan dan Kesihatan Pekerja, 2010).

\section{Memastikan Pengangkutan Awam Selamat Digunakan}

Sistem pengangkutan yang baik dapat memastikan penduduk dan persekitaran berada dalam keadaan harmoni. Dalam era kemajuan dunia, kejayaan komuniti dan ekonomi adalah berkait rapat dengan infrastruktur pengangkutan yang efisien. Bagi Csikszentmihalyi dan Le Fevre (1989), kualiti perkhidmatan melibatkan sikap, masa, peralatan atau model yang sesuai, keluaran yang berkualiti dan kepuasan pelanggan. Sistem pengangkutan yang berkesan juga akan dapat mengurangkan pencemaran udara, menyediakan mod perjalanan yang selesa dan mengurangkan kesesakan. Pengangkutan Darat seperti pengangkutan jalan dan rel merupakan mod utama pengangkutan di Malaysia. Bagi menyelaras kesemua aktiviti tersebut, Bahagian Darat berperanan penting sebagai penjana dan penggerak kepada pembangunan dan pelaksanaan dasar pengangkutan negara. Untuk memenuhi keperluan umum, pelbagai dasar pengangkutan awam digubal bagi memastikan sektor pengangkutan awam darat sentiasa selamat dan efisien berdasarkan kepada keperluan semasa.

Berdasarkan kepada Akta Pengangkutan Jalan (APJ) 1897 dan Akta Keretapi 1991, pelaksanaan penguatkuasaan dan tugas-tugas pengawal seliaan adalah di bawah peranan dan tanggungjawab agensi seperti Jabatan Pengangkutan Jalan (JPJ), Perbadanan Aset Keretapi (PAK), Jabatan Keselamatan Jalan Raya (JKJR) dan Institut Penyelidikan Keselamatan Jalan Raya (MIROS) (Mohd. Zaidi, 2010). Bagi menjamin keselamatan pengguna jalan raya, kenderaan komersial tetap perlu menjalani pemeriksaan berkala di Pusat Pemeriksaan Kenderaan Berkomputer (PUSPAKOM). Pemeriksaan perlu dilakukan dari aspek penyenggaraan kenderaan khususnya tayar dan brek, brek antikunci dan tayar keselamatan, pengehadan terhadap minum alkohol dan memandu. Pihak JPJ dan polis juga perlu menetapkan penggunaan had laju yang bersesuaian bagi van dan bas sekolah yang membawa pelajar. Kesemua ciri tersebut boleh mengurangkan risiko kemalangan jalan raya apabila berlaku musibah. Justeru, pemeriksaan pengangkutan awam darat mestilah sentiasa dipantau dan dikawal selia bagi memastikan keselamatan pemandu, penumpang atau pengguna pengangkutan lain di jalan raya dapat dijamin. Selain itu juga, pemeriksaan pengangkutan awam ini perlu menjadi amalan dalam kalangan pemandu dengan mengamalkan konsep kelestarian alam sekitar untuk meningkatkan kualiti hidup dan kesejahteraan masyarakat seiring dalam memenuhi aspirasi negara menjelang pencapaian Wawasan 2020.

\section{Kesimpulan}

Secara keseluruhannya, langkah-langkah yang dicadangkan adalah mengikut kesesuaian ruangan zon black spot yang terlibat. Dengan mengambil kira maklum balas responden di setiap zon dan lokaliti, adalah wajar PBT turut menggunakannya sebagai sumbang saran dalam usaha memperkasakan ketigatiga domain bandar berdaya huni di zon black spot jenayah di Sabah. Diharapkan agar dengan penjelasan setiap langkah yang dicadangkan ini memberikan satu anjakan perubahan dalam peningkatan kualiti kemudahan fizikal ruangan dalam bandar untuk kegunaan komuniti yang menekankan kepada tiga konsep iaitu keselamatan, keselesaan dan kesejahteraan. 


\section{Penghargaan}

Jutaan terima kasih diucapkan kepada Kementerian Pengajian Tinggi (KPT) atas pembiayaan untuk proses dapatan data (awal) melalui Geran Penyelidikan FRGS 0444-SS-1/2016. Selain itu, tidak dilupakan kepada seluruh responden yang terlibat di lima belas (15) zon black spot di sekitar Kota Kinabalu, Sandakan dan Tawau serta semua agensi yang terlibat dalam menjayakan kutipan data di lapangan iaitu PBT (DBKK, MPS dan MPT), PDRM, JPBD, JPBW, KKTP, AADK dan JPNIN.

\section{Rujukan}

A. Raouf, M. Ben-Daya. (1995). Flexible Manufacturing Systems: Recent Developments. Reference For Modern Instrumentation. Techniques, and Technology, 23, 1-316

Akasah, Z. A. (2008). Model Proses Generik Pengurusan Penyelenggaraan Bangunan Sekolah. Tesis Ijazah Doktor Falsafah. Universiti Teknologi Malaysia: Faculty of Built Environment.

Augustine, T. (2017). Penjagaan Alam Sekitar: Cabaran Dan Pengurusan Sisa Pepejal Domestik. Diakses Pada 10/2/2021 Dalam Https://Www.Malaysian-Ghost-Research.Org/Pengurusan-SisaPepejal-Domestik/

Balsas, C.J.L. (2003). Sustainable Transportation Planning On College Campuses. Transport Policy, $10,35-49$.

Bernama. (21 April 2020). Pengurusan Penyelengaraan Jalan Berturap Sabah Kurang Cekap, Tidak Capai Objektif - Audit Negara. Diakses Pada 11/2/2021 Dalam Https://Www.Sabahpost.Net/2020/04/21/Pengurusan-Penyelengaraan-Jalan-Berturap-SabahKurang-Cekap-Tidak-Capai-Objektif-Audit-Negara/

Bernama. (11 September 2020). Aktiviti Berbasikal Jadi Trend Baharu, 56 Maut Dalam Kemalangan - Bukit Aman. Diakses Pada 11/3/2021 Dalam https://www.astroawani.com/beritamalaysia/aktiviti-berbasikal-jadi-trend-baharu-56-maut-dalam-kemalangan-bukit-aman-272720

Blakely, E., Synder, M. (1997). Fortress America-Gated Communities In The United States. Washington, Usa: Lincoln Institute Of Land Policy

Csikszentmihalyi, M., \& Lefevre, J. (1989). Optimal Experience In Work And Leisure. Journal Of Personality And Social Psychology, 56(5), 815-822.

Haas, R., Hudson, W.R. (1978). Pavement Management Systems. McGraw Hill Book Company: New York.

Jabatan Keselamatan dan Kesihatan Pekerjaan. Kementerian Sumber Manusia. (2010). Tataamalan Industri Keselamatan dan Kesihatan Pekerjaan Bagi Aktiviti Pengangkutan Jalan. Diakses pada 12/2/2021 dalam https://www.dosh.gov.my/index.php/ms/perundangan/kodamalan/pengangkutan/583-01-tataamalan-industri-keselamatan-dan-kesihatan-pekerjaan-bagiaktiviti-pengangkutan-jalan-2010/file

Jamilah, A., Hasrina, M., Hamidah, A. H., Juliana, A. W. (2011). Pengetahuan, Sikap dan Amalan Masyarakat Malaysia terhadap Isu Alam Sekitar. Akademika, 81(3), 103-115

Kementerian Kerja Raya. (2019). Dasar dan Operasi Penyelengaraan Jalan Raya.

Mohd Yusof, H., Lukman, Z. M. (2002). Pembangunan Bandar Mapan dan Kualiti Hidup Masayarakat: Penelitian Sepintas Lalu. Dalam Impak Pembangunan Kualiti Hidup dan Persekitaran. Utusan Publications \& Distributors Sdn. Bhd : Kuala Lumpur

Mohd. Yusof, A., Latiffah, P., Syarifah, M. S. A., Normah, M. (2010). Kesedaran dan Sikap Komuniti dalam Pengurusan Persekitaran Di Wilayah Iskandar, Johor. Jurnal Melayu, 5, 71-86

Mohd. Zaidi, C. M. (2010). Kajian Penentuan Kualiti Perkhidmatan Pengangkutan Awam Di Kota Bharu. Tesis Ijazah Sarjana Sains. Universiti Sains Malaysia

Muhammad R., Rozmi I., Riza A. (2013). Analisis Jarak Perjalanan Mod Pengangkutan Tidak Bermotor. Journal of Business and Social Development, 1(1), 117-127

Nizam, A., Nor Ghani, M. N., Ahmad, M. Z., Abu Hassan, S.M.N. (2011). Hubungan Kecederaan Trafik dengan Pembangunan Ekonomi Malaysia. Jurnal Ekonomi Malaysia, 45, 81 - 87

Norita. J, Nor-Ina. K, Ahmad. T. A. R.. (2015). Pelaksanaan Bandar Selamat dan Pelakuan Jenayah Harta Benda di Kota Kinabalu, Sabah: Satu Penemuan. Prosiding PERKEM, 10, 494-501.

Occupational Safety \& Health Management Office (OSHMO). Universiti Malaysia Pahang. (2019). Ciri-ciri Papan Tanda Keselamatan. 
DOI: https://doi.org/10.47405/mjssh.v6i8.960

Polis Diraja Malaysia. (2019). Statistik Kemalangan Jalan Raya di Malaysia.

Radin, U. R. S. (1998). Analisis Keberkeanan Program Keselamatan Bersepadu Semasa Perayaan Berkembar. Research Report 2/98. Road Safety Research Centre: UPM

Rosniza, A. C. R., Nur Efazainiza, A. B. (2019). Analisis Tahap Kepuasan Pengunjung di Taman Rekreasi Awam Sabah. GEOGRAFIA Online ${ }^{\mathrm{TM} .}$ Malaysian Journal of Society and Space, 15(4), 336-349

Sahar, A. A. D., Muhamad, N. B., Riza, A. R. (2015). Pemodelan Kesediaan Pelajar Beranjak kepada Berbasikal di UKM. Jurnal Kejuruteraan, 27, 95-102

Utusan Borneo. (11 Februari 2019). Srs Komited Cegah Jenayah Di Kawasan Kediaman Walaupun Tidak Bergaji. Diakses Pada 11/3/2021 Dalam Https://Www.Utusanborneo.Com.My/2019/02/11/Srs-Komited-Cegah-Jenayah-Di-KawasanKediaman-Walaupun-Tidak-Bergaji

Zuriatunfadzliah, S., Noraziah, A., Shaharudin, I. (2013). Topophobia Wanita Dan Persekitaran Bandar: Satu Pendekatan Reruang. Akademika, 83(1), 35-43

Zurinah, T., Jalaluddin, A. M. (2018). Kesesuaian Lokasi Pembangunan Perumahan Komuniti Berpagar di Johor Bharu. GEOGRAFIA OnlineTM: Malaysian Journal of Society and Space, 14(2), 125- 